\title{
REGIONAL, ECONOMIC, DEMOGRAPHIC AND SOCIAL (NON)COHESION IN THE REPUBLIC OF NORTH MACEDONIA
}

\author{
Prof. Jorde Jakimovski \\ University Ss Cyril and Methodius \\ Repablic of North Macedonia \\ E-mail: jakjor@isppi.ukim.edu.mk \\ Macedonia
}

\section{ABSTRACT}

In the past period we witnessed major and essential problems in the regions of the Republic of North Macedonia. The difficulty of individual problems, which are often manifested in a more serious form, as a consequence of the deep economic, social and demographic changes in the society, often visible without deeper scientific analysis, referred to partial measures of the economic, social and demographic policy in a short time interval. Apart from the positive impact, some of these measures of the population created certain uncertainties and insecurities regarding the employment, the reduction of migrations and the improvement of the living standard. Therefore, with certain occasional improvements, for a longer period of time some regions and micro-regions do not follow the dynamics of the overall socio-economic development, rather they slow down the dynamics of development.

This paper should give certain elements that can serve in the creation of individual measures, directions and paths for improving the economic, social and demographic structure in the regions in the Republic of North Macedonia. The paper analyses data at the administrative-territorial level by regions in the period 2002-2015. The territory of the Republic of Macedonia is divided into 8 regions (Vardar, Eastern, South-Western, South-Eastern, Pelagonia, Polog, North-Eastern and Skopje Region).

The paper has been divided into three parts:

1. The first part analyses the general economic indicators of the development of the regions: the dynamics of the share of the gross added value, the gross domestic product per capita and the dynamics of the share of investments by regions.

2. The second part presents the natural movements of the population and the utilization of the labour contingent by regions.

3. The third part of the paper presents the changes in the labour force and the dynamics of salary, as the main source of income.

In fact, all indicators are assessed mainly on the basis of available data from secondary sources (State Statistical Office).

Keywords: regional policy, (non)cohesion, gross added value, investments, demographic trends, workforce, salary

\section{Introduction}

The experiences in all societies show that the state has a significant role in defining the strategy and key goals in the development, as well as the construction of mechanisms for their implementation. "... the role of the state in defining the development strategy, and thus the resolution of regional problems is multiple, and it refers primarily to the functioning of the institutions of the whole country, preventing the duplication of economic solutions by the state and its parts, creating conditions for suppression of monopoly behaviour and grey economy, defining a development strategy and especially regional development, as an important element of that strategy "(Arangelovic and Gligorievic, 2013:3). Regional development is in principle a structural problem, which is primarily of economic significance, but it is also very important for p demographic trends. Regional development is a long-term and
persistent problem for every society, because regional problems arise in the form of large differences between the developed https://ijbassnet.com/ and the underdeveloped, and appear as a problem of overpopulation, super-concentration and a pronounced problem of infrastructural nature. The free play of market power leads to a deepening of the gap between the developed and the underdeveloped regions, if these differences need to be reduced, state intervention is necessary (Mirdal, 1957).

The necessary engagement of the state in the area of regional development stems from the fact that large intraregional and interregional differences hinder the development on one hand and encourage the migration movements on the other hand.

1. Regional policy in the Republic of North Macedonia

The current economic and political situation of the Republic of North Macedonia, in addition to many other problems, is characterized by the presence of large differences in the level of development between the regions.

The Assembly of the Republic of North Macedonia in 2007 adopted the Law on Balanced Regional Development http://dx.doi.org/10.33642/ijbass.v6n1op3 


\section{CCenter for Promoting Education and Research (CPER) USA}

WWW.cpernet.org

which defines the basic goals of the policy for stimulation of balanced regional development, as follows: Balanced and sustainable development of the whole territory of the Republic of North Macedonia, reduction of disparities between and within the planning regions, increasing the competitiveness of the planning regions, preserving and developing a special identity of the planning regions and supporting inter-municipa and cross-border cooperation of the local self-government units (Article 3 of the Law). However, in the Republic of North Macedonia, much more attention is paid to structural problems than to regional development, despite the fact that regional development is a structural problem in the full meaning of the word. The effects of the transition are far weaker in the underdeveloped regions, due to underdeveloped utility infrastructure, the emigration of human capital and low level of development of the social activities. The image of the socioeconomic difference is manifested through the privileged position of the economic branches, the uneven distribution of business entities, demographic trends, regional specifics, unemployment, social stratification and the like. In conditions of profound economic, political and social changes, the results lagged behind and caused an increase in inequality, a decline in production, the abandonment of rural areas with large migration in the city, the metropolis of Skopje and abroad. In the East region "if they have the opportunity to choose a place of residence, $42.7 \%$ would choose their life outside the Republic of North Macedonia" (Jakimovski, 2017: 170).

Faced with the problem of uneven regional development, the Republic of North Macedonia has prepared a strategic document that comprehensively reviews this very important and delicate issue. The Strategy for Regional Development of the Republic of North Macedonia 2009-2019 is concerned (Official Gazette No. 119/2009). The strategy highlights two main strategic goals:

- Competitive planning regions characterized by dynamic and development and
- Greater demographic, economic, social and spatial cohesion between and within the planning regions in the Republic of North Macedonia.

In the aforementioned strategy, the priorities and measures for achieving the strategic goals are proposed (Strategy, 2009-2019, 2009, p. 27-36). Although the balanced development is important for our country, the strategy for balanced development is development-oriented, because we are lagging behind in economic development, but the low share of investments and gross domestic product per capita, modest employment, emigration of human capital are the main reasons for unbalanced economic development. In addition, the differences in the construction of the economic and communal infrastructure have not been removed even after 2017, but on the contrary, they increase.

\section{Dynamics of certain economic indicators}

The privatization process has a significant impact on the regional differentiation in North Macedonia, that is the basis of conceiving and implementation of the ownership transformation of our economy. Privatization has led to a major polarization of income and wealth among the population, manifested at local, regional and national levels. Such a policy has an implication on the regional development: a high share of investments in Skopje and major cities, the situation on the labour market shows negative tendencies, the problems of the underdeveloped regions are neglected, the metropolisation process is strengthened, which widens the gap between the big and the small cities, municipalities and settlements, the devastated areas continue to expand, because many industrial enterprises are disbanded, the migration village-city is continuously rising, which causes a large part of the territory of the country to remain without population able to work. The deepening of the difference between the developed and the underdeveloped regions in the Republic of North Macedonia that are lasts longer and has a chronic character, and the problem of sustainable regional underdevelopment becomes serious and sensitive in economic terms.

Table1. Dynamics of participation of gross added value (Republic of North Macedonia=100.00 \%)

\begin{tabular}{|c|c|c|c|c|c|c|c|}
\hline & 2010 & 2011 & 2012 & 2013 & 2014 & 2015 & 2016 \\
\hline $\begin{array}{l}\text { Republic of North } \\
\text { Macedonia }\end{array}$ & 100.00 & 100.00 & 100.00 & 100.00 & 100.00 & 100.00 & 100.00 \\
\hline Vardar Region & 7.15 & 7.30 & 7.77 & 8.22 & 7.98 & 7.98 & 7.76 \\
\hline East Region & 8.66 & 8.67 & 8.26 & 8.06 & 8.23 & 8.04 & 7.90 \\
\hline Southwest Region & 8.19 & 8.33 & 8.07 & 7.84 & 7.89 & 8.38 & 8.21 \\
\hline Southeast Region & 8.95 & 9.38 & 9.36 & 9.21 & 10.00 & 9.80 & 9.97 \\
\hline Pelagonia Region & 12.10 & 11.29 & 10.90 & 11.26 & 11.07 & 10.79 & 10.94 \\
\hline Polgg Region & 7.71 & 7.77 & 7.29 & 7.52 & 7.09 & 6.97 & 7.14 \\
\hline Northeast Region & 4.73 & 5.51 & 5.53 & 5.31 & 4.96 & 5.17 & 4.98 \\
\hline Skopje Region & 42.51 & 41.75 & 42.82 & 42.58 & 42.78 & 42.87 & 43.09 \\
\hline
\end{tabular}

Source: Republic of Macedonia, State Satistical Office (2013, 2015 and 2019) 
The data on gross added value unambiguously show and with the lowest participation the Northeast Region with 5\% the dominance of the Skopje Region over the other planning (state in 2016). In addition to the symbolic increase of the gross regions. Namely, the Skopje Region takes the leading place in added value in the Southeast Region and decrease in the the structure of gross added value in the Republic of North Pelagonia Region in relation to the previous years, the Macedonia with 43\%, followed by the Pelagonia Region with percentage share of the other regions in the gross added value $11 \%$, the Southeast Region with $10 \%$, the Vardar, the East and has not changed at all.

Southwest Region with about $8 \%$ the Polog Region with $7 \%$

Table 2. Gross domestic product, per capita (Republic of North Macedonia $=100.0$ )

\begin{tabular}{|c|c|c|c|c|c|c|c|}
\hline & 2010 & 2011 & 2012 & 2013 & 2014 & 2015 & 2016 \\
\hline $\begin{array}{l}\text { Republic of North } \\
\text { Macedonia }\end{array}$ & 100.0 & 100.0 & 100.0 & 100.0 & 100.0 & 100.0 & 100.0 \\
\hline Vardar Region & 95.4 & 97.8 & 10.2 & 110.5 & 107.5 & 108.0 & 105.3 \\
\hline East Region & 98.9 & 99.5 & 95.2 & 93.3 & 95.7 & 93.9 & 92.7 \\
\hline Southwest Region & 75.9 & 77.4 & 75.3 & 65.4 & 74.1 & 78.8 & 77.4 \\
\hline Southeast Region & 106.5 & 115.2 & 114.1 & 109.6 & 119.2 & 116.9 & 119.1 \\
\hline Pelagonia Region & 106.2 & 99.6 & 96.5 & 100.0 & 98.7 & 96.9 & 9.4 \\
\hline Polog Region & 50.3 & 50.6 & 47.4 & 48.8 & 45.9 & 45.1 & 46.2 \\
\hline Northeast Region & 55.5 & 64.8 & 65.0 & 62.3 & 58.3 & 60.8 & 58.6 \\
\hline Skopje Region & 145.0 & 141.8 & 144.0 & 143.5 & 143.6 & 143.3 & 143.4 \\
\hline
\end{tabular}

When the gross domestic product per capita is Polog Region has below the half of the gross domestic product concerned, the Skopje Region with EUR 6692 has a 43.4\% per capita (EUR 2155 that is 46.2\%), the Northeast Region increase compared to the national average (EUR 4 666). EUR 2 737, that is 58.6\%, while the Southwest Region EUR 3 However, this is not the case with the remaining regions. The 612 that is $77.4 \%$ of the national average (state in 2016).

Table 3. Dynamics of participation of investments in fixed assets (Republic of North Macedonia=100.00 \%)

\begin{tabular}{|c|c|c|c|c|c|c|c|}
\hline & 2010 & 2011 & 2012 & 2013 & 2014 & 2015 & 2016 \\
\hline $\begin{array}{l}\text { Republic of North } \\
\text { Macedonia }\end{array}$ & 100.00 & 100.00 & 100.00 & 100.00 & 100.00 & 100.00 & 100,00 \\
\hline Vardar Region & 6.12 & 5.43 & 4.45 & 6.87 & 5.95 & 6.57 & 7.26 \\
\hline East Region & 9.59 & 4.69 & 5.22 & 8.79 & 8.23 & 9.81 & 8.17 \\
\hline Southwest Region & 4.69 & 4.03 & 4.69 & 4.70 & 7.67 & 10.16 & 9.97 \\
\hline Southeast Region & 6.96 & 5.23 & 4.33 & 5.37 & 5.62 & 4.92 & 7.24 \\
\hline Pelagonia Region & 7.59 & 5.39 & 9.11 & 9.03 & 6.74 & 7.67 & 9.06 \\
\hline Polog Region & 7.86 & 7.65 & 8.23 & 6.35 & 5.71 & 6.03 & 4.68 \\
\hline Northeast Region & 2.59 & 1.21 & 2.33 & 2.09 & 2.06 & 2.40 & 1.70 \\
\hline Skopje Region & 54.63 & 66.35 & 61.63 & 56.80 & 68.02 & 52.44 & 51.94 \\
\hline
\end{tabular}

Source: Republic of Macedonia, State Satistical Office (2013, 2015 and 2019)

The dynamics of the structure of fixed assets investments is also devastating, which are not only in line with the proclaimed aims of the strategy, but are increasingly contributing to the the percentage of investments in fixed assets continues, it can distancing from them. About $52 \%$ of the total investments in be detrimental to many regions, that is micro-regions and will fixed assets in the Republic of North Macedonia belong to the directly contribute to their demographic discharge.

Skopje Region, whereas the Northeast Region participates less than $2 \%(1,7 \%)$ in the total investments (state in 2016).
These economic movements directly reflect the demographic trends between the regions, especially the villagecity movement, but also the migration abroad. If we come from 
the assumption that every person economically rationally tends and more even distribution of the population, raising the level to be employed in the bigger cities and Skopje. If it is known of social development, supporting areas with special that in Skopje and the larger cities there are far more job development needs, in the planning regions in the Republic of openings, the chances of employment are greater. It is often the North Macedonia have not been achieved. However, not only is case that in less developed regions there is no sufficient the situation worsening, but negative demographic and social professional workforce. For these cities, the daily migrations movements are even intensifying.

are also more characteristic. Generally speaking, the 3. Demographic movements demographic contraction is directed towards Skopje. This

Compared with the national average, the East Region creates two types of problems. On the one hand, it will make continues with the lowest birth rate (in 2010, the birth rate for the unemployment problem more serious, and on the other the East Region was lower by 1.9 per mil or in 2018 by 2.4 per hand it will cause demographic devastation of the less mil regarding the birth rate which refers to the whole developed regions. With the devastation of small towns and population of the Republic of North Macedonia or simply said, village areas, one can say that North Macedonia is losing its in the East Region there were less 1.9 children born in 2010, breath in economic development.

that is, 2.4 children in 2018 per 1000 inhabitants than at the

The data show that the encouraging of economic national level). The highest birth rate was shown by the Skopje growth, increasing and more even distribution of investments, Region (13.5 per mil in 2010, that is, 12.7 per mil in 2018). developing modern infrastructure, demographic revitalization

Table 4. Per 1000 inhabitants

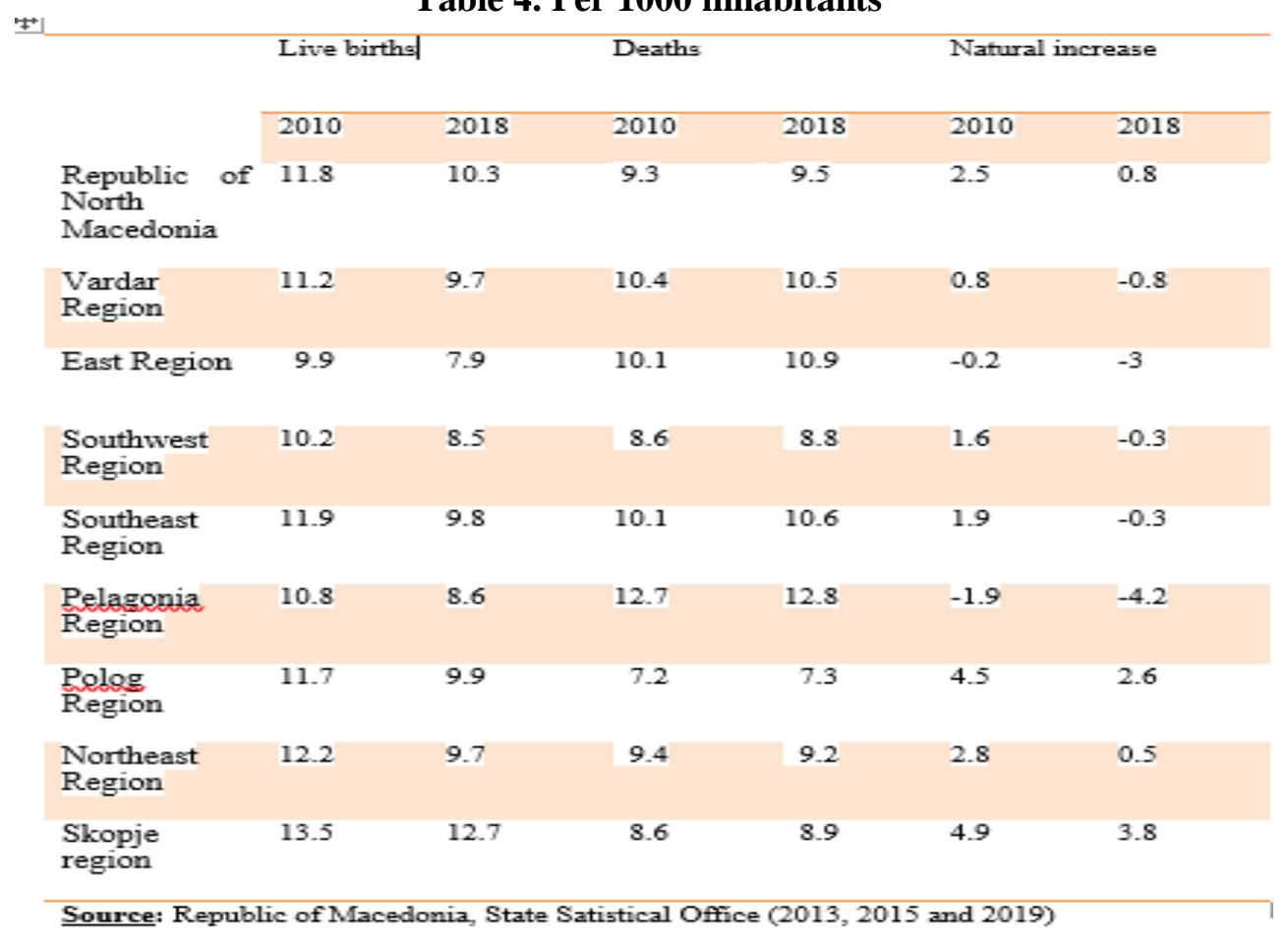

Mortality rates are highest in the Pelagonia Region, the Namely, in the research period 2005-2012, the East Region mortality rate ranging from 12.7 deaths per 1000 inhabitants in shows a total loss of human potential of 3238 persons or $1.8 \%$ 2010 to 12,8 deaths per 1000 inhabitants in 2018 . of the population in the middle of 2012"(Study: Demographic

As can be seen from the data from Table 4, the number Development for the Spatial Plan of the East Planning Region, of deaths in 2018 in the Pelagonia Region, East, Vardar, 2014:27).

Southeast and Southwest Region is significantly higher than the The population in four regions (Vardar, East, Southwest number of live births (negative natural increase). Such a and Pelagonia) in 2018 is 20624 inhabitants or 2.6\% lower tendency, especially if accompanied by negative migration than in the 2002 census. It is alarming that the decline in the flows, leads to permanent direct consequences in terms of the number of the population is still the largest in the demographic situation in terms of depopulation of the regions, underdeveloped micro-regions and municipalities, and with change in the demographic structure, but also in terms of such trends certain geographical areas will remain completely economic, social and in any other perspective of the regions. desolate, and without any prospects for further development. In 
the period 2002-2018 the Skopje Region is differentiated by the solutions for opening new jobs (82.4\%), solutions for transport largest population increase of 8.8\% (51 071 inhabitants). With and road construction (72.5\%) is registered in the Northeast above-average population growth (Republic of North Region" (Jakimovski, 2017:1057).

Macedonia has an increase of $2.6 \%$ ), the Polog Region (5.9\% or 17632 inhabitants) is also singled out.

The population in the Republic of North Macedonia as changes in the aging of the workforce in the region. It is of a whole does not decrease, but in the short and long period great importance to determine the burden on the working some regions/micro-regions face decreasing of the total and contingent of the population, which is a demographic able-bodied population, due to the aging and emigration framework for the formation of the largest part of the process. Therefore, large area in the regions remains uncovered workforce, depending on the possibilities for activating the by population (demographically empty), their resources workforce. Indicators for utilization of the work contingent are unused, and in Skopje and the larger urban centres there is an the age dependency coefficient for the total population, the excessive concentration of population that produces negative coefficient for age dependence of youth and the age consequences in the economic, social, spatial and dependency coefficient of the elderly.

environmental domain. There are ineffective public sector services, a feeling of decay of the surroundings, lack of trust in deg the government, depression, reduced social organization, young people (0-14 years of age) and with the elderly (65+ declining services from the private sector, empty houses, poor years) that is, the burden of the work contingent with the preliving conditions, lack of social and cultural content for young employment and the post-employment contingent.

people and closing of public institutions (schools, clinics, post

The coefficient of age dependence of the young people offices and shops). Agriculture is the only source of revenue is the degree of burden on the working age population with the that cannot sustain the micro system and the diverse needs of youth contingent, that is persons with the pre-employment the population. Except, small incomes, the great dissatisfaction capacity (0-14 years of age).

of the population in those areas is in the opening of new jobs,

The coefficient of age dependence of the elderly is the underdeveloped utility infrastructure roads, water supply, degree of burden on the working age population with the sewerage and the like. Namely, "in average $52.4 \%$ of the contingent of the old population, that is, the persons of the postvillage population is dissatisfied with the work of the local self- employment age (65 years or more).

government in finding solutions for job creation, $43 \%$ in

The depending old population can greatly burden the finding solutions for transportation, construction and public spending (pensions, health care, etc.) because a maintenance of roads, and $38 \%$ in solutions for water supply persistently smaller number of working people support a and sewerage. The greatest dissatisfaction with finding constantly growing number of pensioners.

Table 5. Age dependence coefficient

\begin{tabular}{|c|c|c|c|c|c|c|}
\hline & \multicolumn{2}{|c|}{$\begin{array}{l}\text { Coefficient of total age } \\
\text { dependence }\end{array}$} & \multicolumn{2}{|c|}{$\begin{array}{l}\text { Coefficient of age dependence } \\
\text { of the young }\end{array}$} & \multicolumn{2}{|c|}{$\begin{array}{l}\text { Coefficient of age dependence of } \\
\text { the elderly }\end{array}$} \\
\hline & 2002 & 2015 & 2002 & 2015 & 2002 & 2015 \\
\hline $\begin{array}{l}\text { Republic of } \\
\text { North } \\
\text { Macedonia }\end{array}$ & 46.4 & 41.9 & 30.9 & 23.7 & 15.5 & 18.2 \\
\hline Vardar Region & 43.1 & 42.7 & 27.0 & 22.6 & 16.1 & 20.1 \\
\hline East Region & 42.1 & 40.4 & 26.1 & 20.1 & 16.0 & 20.3 \\
\hline $\begin{array}{l}\text { Southwest } \\
\text { Region }\end{array}$ & 50.4 & 36.4 & 35.2 & 21.0 & 15.2 & 15.4 \\
\hline $\begin{array}{l}\text { Southeast } \\
\text { Region }\end{array}$ & 43.9 & 42.1 & 28.5 & 23.3 & 15.4 & 18.8 \\
\hline $\begin{array}{l}\text { Pelagonia } \\
\text { Region }\end{array}$ & 49.0 & 45.0 & 26.6 & 22.3 & 22.4 & 22.7 \\
\hline Polog region & 51.2 & 35.1 & 39.4 & 23.0 & 11.8 & 12.1 \\
\hline $\begin{array}{l}\text { Northeast } \\
\text { Region }\end{array}$ & 48.9 & 41.6 & 33.7 & 24.8 & 15.2 & 16.8 \\
\hline Skopje Region & 43.6 & 47.0 & 29.2 & 26.9 & 14.4 & 20.1 \\
\hline
\end{tabular}




\section{(C) Center for Promoting Education and Research (CPER) USA}

WWW.cpernet.org

Statistical data show that the coefficient of total age the country's state policy without proper strategy, poorly dependence in the Southwest Region shifted from $50.4 \%$ in conducted privatization, high level of corruption, non2002 to $36.4 \%$ in 2015. This shift derives from the significant enforcement of law and irresponsibility of the government in reduction in the burden of the working age population with the Republic of North Macedonia. persons in the pre-employment ages, 0-14 years of age (from $35.2 \%$ to $21.0 \%$ ).

The coefficient of the total working ability in the analysed period shows that the number of pre-employment contingent (0-14 years) decreases in all regions in relation to the working contingent, while the age dependence coefficient of the elderly shows an increase in the number of the postemployment contingent in all regions, but the largest increase has been noticed in the Skopje Region (from 14.4\% to 20.1\%), East Region (from $16.0 \%$ to $20.3 \%$ ) and Vardar Region (from $16.1 \%$ to $20.1 \%$ ) .

The population imbalance shows on one hand positive movements in some regions (Skopje, Polog, Northeast, Southeast) in contrast to the demographic devastation in the East Region, Pelagonia Region, Vardar Region, Southwest Region. The multiple negative effect of these movements is felt in many segments: in the age structure of the population, internal and external migration, employment, social environment, etc. All of these phenomena are a consequence of

\section{Labour and salary}

The Republic of North Macedonia with an unemployment rate of $20.7 \%$ certainly does not give good prospects for social integration of the labour force, especially if we take into account the unemployment rate of the young population (15-24 years) which is $44.0 \%$ (Labour market, 2018/IV). It means that nearly half at the age of 15-24 years is prevented from earning a salary and creating work experience.

"... the increase in employment actually creates a change in the economic and social structure, changing the character of the economy ..." (Mihajlovic, 1982: 322). According to Mihajlovic, the participation of employees in the working population gives a more vivid representation of the development and the reasons for underdevelopment, than the amount of the gross domestic product per capita.

The unemployed often have a limited access to revenues, to social, healthcare, educational and cultural services, accompanied by poverty and malnutrition.

Table. 6 Activity rates of the population aged 15 years and over by regions

\begin{tabular}{|c|c|c|c|c|c|c|}
\hline & \multicolumn{2}{|c|}{ Activity rate } & \multicolumn{2}{|c|}{ Employment rate } & \multicolumn{2}{|c|}{ Unemployment rate } \\
\hline & 2010 & 2018 & 2010 & 2018 & 2010 & 2018 \\
\hline $\begin{array}{l}\text { Republic of } \\
\text { North }\end{array}$ & 56.9 & 56.9 & 38.7 & 45.1 & 32.0 & 20.7 \\
\hline \multicolumn{7}{|l|}{ Macedonia } \\
\hline $\begin{array}{l}\text { Vardar } \\
\text { Region }\end{array}$ & 59.1 & 60.0 & 37.2 & 50.4 & 37.0 & 15.9 \\
\hline East Region & 58.6 & 60.4 & 49.0 & 53.4 & 16.4 & 11.5 \\
\hline $\begin{array}{l}\text { Southwest } \\
\text { Region }\end{array}$ & 55.5 & 55.9 & 36.5 & 39.4 & 34.3 & 29.6 \\
\hline $\begin{array}{l}\text { Southeast } \\
\text { Region }\end{array}$ & 69.9 & 67.5 & 61.9 & 60.2 & 11.5 & 10.9 \\
\hline $\begin{array}{l}\text { Relagonia } \\
\text { Region }\end{array}$ & 63.8 & 64.9 & 42.4 & 55.0 & 33.6 & 15.3 \\
\hline Bolog Region & 46.7 & 50.5 & 32.3 & 35.8 & 30.8 & 29.0 \\
\hline $\begin{array}{l}\text { Northeast } \\
\text { Region }\end{array}$ & 58.3 & 52.5 & 21.7 & 33.7 & 62.8 & 35.9 \\
\hline $\begin{array}{l}\text { Skopje } \\
\text { Region }\end{array}$ & 54.7 & 54.2 & 36.7 & 43.7 & 33.0 & 19.3 \\
\hline
\end{tabular}


Based on the data in Table 6, the greatest reduction in the labour force is registered in the Northeast region, from $58.3 \%$ to $52.5 \%$, whereas there is an increase in the Polog Region from $46.7 \%$ to $50.5 \%$. The Northeast Region still has the highest unemployment rate (35.9\%). This rate is $15.2 \%$ above the national unemployment rate.

The greatest and most serious causes of the discharge of certain regional units are probably the low standard of living and the uncertain existence of people living in those areas. Namely, in the East Region " $43.7 \%$ of the households are most affected by insufficient income, $38.1 \%$ by no conditions for employment, $8.4 \%$ by poor conditions for medical treatment ..." (Jakimovski, 2017: 169). For most of the people living in the Macedonian society, the salary is the main source of income (65.6\% in 2018, Statistical Review: Revenue, Consumption and Prices, 4.4.18.01/892, page 13). 61.2\% of employees in the Republic of North Macedonia have a salary of less than 325 euros (State Statistical Office, Labour Force Survey 2017, p. 67, Statistical Review 2.4.18.03/894, 2018). The minimum necessary living standard of a four-member household usually exceeds the average salary earnings in the household, since the average household employment rate in North Macedonia is $1.01 .50 \%$ of the households with two adults and with three or more dependent children live in poverty (State Statistical Office, Poverty Line, Announcement Laeken Indicators of Poverty in 2018, Announcement No. 4.1.19.116).

Table 7. Average net salary per employee (Republic of North Macedonia $=100.0)$

\begin{tabular}{|c|c|c|c|c|c|c|c|c|c|}
\hline & 2010 & 2011 & 2012 & 2013 & 2014 & 2015 & 2016 & 2017 & 2018 \\
\hline $\begin{array}{l}\text { Republic of North } \\
\text { Macedonia }\end{array}$ & 100.0 & 100.0 & 100.0 & 100.0 & 100.0 & 100.0 & 100.0 & 100.0 & 100.0 \\
\hline Vardar Region & 77.1 & 77.3 & 79.7 & 79.1 & 79.2 & 79.4 & 79.2 & 79.4 & 81.5 \\
\hline East Region & 72.6 & 77.3 & 79.7 & 72.5 & 73.8 & 74.3 & 74.4 & 77.0 & 80.0 \\
\hline Southwest Region & 89.6 & 88.7 & 89.6 & 91.4 & 90.9 & 89.8 & 89.7 & 88.4 & 88.5 \\
\hline Southeast Region & 77.5 & 77.6 & 79.4 & 77.8 & 78.2 & 77.3 & 78.4 & 79.8 & 79.4 \\
\hline Relagonia Region & 93.8 & 92.6 & 91.7 & 93.6 & 91.2 & 92.3 & 92.2 & 92.4 & 92.8 \\
\hline Rolog Region & 93.2 & 94.9 & 95.5 & 95.8 & 95.5 & 94.1 & 96.2 & 95.1 & 93.2 \\
\hline Northeast Region & 84.6 & 81.6 & 79.0 & 77.6 & 77.2 & 76.9 & 75.9 & 77.4 & 76.7 \\
\hline
\end{tabular}

\begin{tabular}{llllllllll} 
Skopje Region & 117.7 & 118.4 & 117.3 & 116.8 & 118.1 & 118.1 & 117.5 & 116.8 & 115.9 \\
\hline
\end{tabular}

Source: Republic of Macedonia, State Satistical Office (2013, 2015 and 2019)

The Northeast Region have the lowest earnings, the average net salary per employee is at the level of $76.7 \%$ of the average in the country, while in the Skopje Region it is $115.9 \%$ (state in 2018).

\section{Conclusion}

The reduction of the level of natural growth, stimulated by the emigration of the young population, causes fundamental changes in the age structure of the population in a larger number of municipalities, as well as a growing number of very old people. Based on the demographic indicators, the birth rate, mortality, natural growth of the East and Pelagonia region can be placed in the range of regions with seriously negative demographic trends:

- The population in the Pelagonia, East, and Vardar region has not been renewed for several years, fertility is below the level of the necessary replacement of the generation;

- Accelerated aging process of the population;

- Accelerated process of immigration of the young population;

- Accelerated process of resettlement and extinction of rural settlements;
- Lack of investments to build the necessary infrastructure.

The system of institutions and measures that directly or indirectly influence the reproduction is being created during this whole time without any attention to its demographic effects.

It should be emphasized that it is not about marginal demographic problems, but about such - depopulation - that, if left unchanged, will lead to tectonic demographic disorders in the regions. The policy holders for stimulating balanced regional development (the Government of the Republic of North Macedonia, the Council for Balanced Regional Development, the Ministry of Local Self-Government, the Council for Development of the Regions) should devote more attention to the negative economic, demographic and social trends in the regions in the short-term period.

By the regional policy, through investments and stimulating capital inflows, the state should strive to remove and mitigate the constraints faced by underdeveloped areas, that is, to enable them to accelerate their development. This applies to micro-regions with special developmental problems, in order for that micro-region to compensate for its structural 
weaknesses. Such assistance to be effective requires continuity small town settlements and rural centres that will provide the and intensive support of the state over a longer period of time.

It is not possible to provide quality regional
development, if the state does not provide an adequate socionecessary services to the surrounding villages.

Assistance in these areas should be accomplished with measures (non-repayable funds or no interest loans, economic mechanism that will enable: creation of a new tax incentives) for development of additional activities of rural working and economic structure as required by the modern households (tourism, domestic workshops), state financing of economy, adaptation of the educational system to the demands communal infrastructure and necessary facilities for social of the job openings, social security of the citizens, functioning standards, free assistance in education, obtaining building of the legal state, mutual reintegration of regions with regions permits, introducing into entrepreneurship and the like.

in other countries, creation of conditions for the flow of people, capital and services.

One must finally start to solve the problems in this area, by defining a new strategy for regional development with the task and goal in:

In order to achieve a balanced spatial distribution, the Government, the Council for Balanced Regional Development, the Ministry of Local Self-Government and the Council for Development of the Planning Regions, should regularly monitor - as a consequence of their economic and social

Urgent construction and improvement of the communal policies, sectoral priorities and investment in infrastructure and social infrastructure, especially in the underdeveloped the natural movement of the population, the internal and micro-regions (roads, traffic, clinics, schools, shops).

external migration in the region, the policies for productive

As the demographic and social processes can deepen employment of the young population and the policies of the the existing demographic gap between the regions in the social security system for elderly people.

Republic of North Macedonia, additional efforts are needed to

The Regional Development Strategy should be remake these processes change. Basically, the underdeveloped examined. Although there is some improvement in the urban regions/micro-regions must be attractive for the young and infrastructure and environmental strategies with the task of educated workforce only if there is economic convergence, providing a healthy environment for the urban population, because the development of the economy is the most relevant similar and accelerated activities through specific projects factor for retaining the existing population and attracting should also be implemented in rural areas.

immigrants.

A strategy for demographic rebuilding should be

Diversification of the economic structure, industry and developed, which will contain additional measures for retaining even tertiary activities is needed. "Only one sector dependent the existing population and attracting new population in order to areas suffered major damage, due to increased mobility and encourage higher natural growth. By retaining the population, rapid changes in the comparative advantage" (William and economic vitality will be enabled, and in demographically Carren, (1995) 2009: 74). In this case, the dispersion and devastated areas, it is essential for the community's survival. It development of the industry would have a significant impact. is obvious that current measures to encourage demographic Such development would use local resources and the available development are not enough. Considering the comprehensive workforce. Low earnings in classical industrial branches issue of demographic development, a separate document needs (textiles, leather, construction materials) and food industry in to be prepared, which will analyse in more detail the micro-regions (rural areas) can be compensated by additional possibilities for improving the current demographic situation. agricultural income. It is necessary to develop a network of Immediate implementation of the population census.

\section{References}

1. Arangjelovic, Z. \& Gligorijevic, Z. (2013). Government's Role in Creating the Conditions for Balanced Regional Development in Proceedings of $18^{\text {th }}$ Scientific Conference: Regional Development and Demographic Flows of Southeastern European Countries, 2013 Faculty of Economics in the University of Nis, pp. 3-15.

2. Law on Balanced Regional Development. (2007). Official Gazette of the Republic of Macedonia No. 63

3. Jakimovski, J. (2017). Citizens Participation in Addressing Local Problems: A Case Study of Republic of Macedonia, in Proceedings of $8^{\text {th }}$ International Scientific Rural Development 2017, Article DOI: http:doi.org/10.15544/RD.2017.215, In Press, Http://conf.rd.asu.lt/index.php/rd/article/view/436.

4. Jakimovski, J. (2017). Relations Between the Social and Demographic Changes in the republic of Macedonia: Case Study of the East Region, Journal of Sociology and Social Work, Vol. 5, No. 2, pp. 161-172.

5. Myrdal, G. (1957). Economic Theory and Under-Developed regions, Duskwort, London. 
6. Михаиловиќ, К. (1982). Социјални и економски ичиљеви регионалног развоја, Економск Зборник Книга II, Дугорочни развој Југославије- остварња иильеви потребе, Српска академија наука и уметности, Београд, 331323.

7. Republic of North Macedonia, State Statistical Office, Regional yearbook. Regions in the Republic of North Macedonia, 2013, 2015 and 2019. Skopje, https://www.stat.gov.mk.

8. Republic of Macedonia, State Statistical Office. (2004). Census of population, households and dwellings in the Republic of Macedonia, 2002. Total population, households and dwellings according to the territorial organization of the Republic of Macedonia, Skopje, https://www.stat.gov.mk

9. Republic of Macedonia, State Statistical Office.(2015) Statistical Review: Population and Social Statistics, Population percentages on 30. 06. 2015 and 31.12.2015 by gender and age, by municipalitiles and statistical regions: ( NUTS 32007) Skopje, https://www.stat.gov.mk

10. Republic of North Macedonia, State Statistical Office, News Release: Poverty line, Laeken poverty indicators in 2018, Skopje, https://www.stat.gov.mk.

11. Regional Development Strategy of the Republic of Macedonia 2009-2019. (2009). Official Gazette of the Republic of Macedonia No. 119 , https://www.stat.gov.mk

12. Study: Demographic Development for the Spatial Plan of the East Planning Region, (2014). Institute for Sociological, political and Juridical Research, Skopje, (Jakimovski, J., Serafimovska, E. Jakjimovska,V., Simoski,A. and Bogdanovski, M.).

13. William A. Galton and Karen J. Bachler. (1995). 2009. Rural Development in the United States, Connecting Theory, Practice, and Possibilities. Translated by Nikola Utkovski. Skopje: Magor. 